\title{
POST-HARVEST CONSERVATION OF "PIONEIRA" BANANA (Musa spp.) USING BABAÇU COCONUT OIL
}

\author{
Fernando Henrique Cardoso Veras ${ }^{1}$, Fredson Leal de Castro Carvalho², Lindomar Braz Barbosa Júnior ${ }^{3}$, Rayane \\ Reis Sousa ${ }^{4}$, Railton Reis Arouche ${ }^{1}$, Edvan Carlos de Abreu ${ }^{1}$, Roberta Freitas de Souza Lobo ${ }^{5}$
}

\author{
${ }^{1}$ Engenheiros Agrônomos, Instituto Federal do Tocantins (IFTO), Povoado Santa Tereza, Km 5 s/n - Zona Rural -Araguatins/TO - CEP: \\ $77.950-000$ \\ 2Engenheiro Agrônomo, Mestrando em Agroenergia, Universidade Federal do Tocantins (UFT), Avenida NS 15, Quadra 109 Norte - \\ Plano Diretor Norte - Palmas/TO - CEP: 77.001-090 \\ ${ }^{3}$ Engenheira Agrônoma, Mestranda em Agricultura e Ambiente, Universidade Estadual do Maranhão (UEMA), Praça Gonçalves Dias, \\ s/n - Centro - Balsas/MA - CEP: $65.800-000$ \\ ${ }^{4}$ Engenheiro Agrônomo, Mestrando em Proteção de Plantas, Instituto Federal Goiano (IF Goiano), Rodovia Prof. Geraldo Silva \\ Nascimento, Km 2,5 - Zona Rural - Urutaí/GO - CEP: 75.790-000 \\ ${ }^{5}$ Professora Doutora do Instituto Federal do Tocantins (IFTO), Povoado Santa Tereza, Km 5, s/n - Zona Rural - Araguatins/TO - CEP: \\ 77.950-000
}

*Autor para correspondência: Fredson Leal de Castro Carvalho, fredson_tecnicoagro@hotmail.com

\begin{abstract}
The use of fruit coatings allows maintaining longer post-harvest quality of fruits, preserving their physicochemical characteristics (appearance, taste and texture) and increasing commercial acceptance. Thus, this work aimed to evaluate the effect of the application of babassu coconut oil as coating on 'Pioneer' banana (Musa AAAB) to preserve its quality characteristics and increase shelf life. The experiment was carried out at the Laboratory of soils of the Federal Institute of Tocantins, Araguatins - TO. Completely randomized design was adopted in a $6 \times 5$ factorial scheme (six purified babassu coconut oil concentrations as vegetal coating, $\mathrm{T} 1-0.0 \%$, $\mathrm{T} 2-1.0 \%, \mathrm{~T} 3-2.0 \%, \mathrm{~T} 4-3.0 \%, \mathrm{~T} 5-4.0 \%, \mathrm{~T} 6-5.0 \%$ and five evaluation times, $1^{\text {st }}, 3^{\text {rd }}, 6^{\text {th }}$ and $9^{\text {th }}$ and $12^{\text {th }}$ days after coating application), with four replicates. Products were applied to fruits by dipping, naturally dried and stored at room condition for 12 days. Variables evaluated were peel colour, total solids, $\mathrm{pH}$, fresh mass loss. Data were submitted to normality and homogeneity tests, fulfilling the assumptions, analysis of variance was performed, with significance measured by the $F$ test $(p<0.05)$. Due to the quantitative variation sources (oil concentrations and evaluation times), regression analyzes were performed for all variables except for score scale method. Regarding fruit peel colour, babassu coconut oil had relevant effect, and treatment with $5 \%$ babassu oil concentration was the one that kept green peel colour longer than the other treatments. According to results obtained, the use of babassu coconut oil in post-harvest conservation of 'Pioneer' banana had significant effects, since all treatments with babassu oil concentrations showed efficiency in inducing delayed ripening, especially providing delayed increase in ${ }^{\circ}$ Brix content of fruits.
\end{abstract}

KEY WORDS: conditioning, biofilms, Musa AAAB.

\section{CONSERVAÇÃO PÓS-COLHEITA DE BANANA "PIONEIRA" (Musa spp.) COM USO DE ÓLEO DE COCO DE BABAÇU}

RESUMO: O uso de revestimentos em frutas permite manter por mais tempo sua qualidade pós-colheita, conservando suas características físico-químicas (aparência, sabor e textura) e aumentando a valorização comercial. Com isso, este trabalho teve por objetivo avaliar o efeito da aplicação de óleo do coco babaçu como revestimento da banana 'Pioneira' (Musa AAAB) visando preservar suas características de qualidade e aumentar sua vida útil. $O$ experimento foi realizado no laboratório de solos do Instituto Federal do Tocantins, município de Araguatins - TO. Adotou-se o delineamento inteiramente casualizado, no esquema fatorial $6 \times 5$ (seis concentrações de óleo purificado do coco babaçu como revestimento vegetal sendo eles T1 - 0,0\%, T2 - 1,0\%, T3 - 2,0\%, T4 - 3,0\%, T5 - 4,0\%, T6 - 5,0\% e cinco épocas de avaliações aos $1^{\circ}, 3^{\circ}, 6^{\circ}$ e $9^{\circ}$ e $12^{\circ}$ dias após aplicação dos revestimentos), com quatro repetições. Os produtos foram aplicados nos frutos por imersão, secos naturalmente e 
armazenados em condição ambiente por 12 dias. As variáveis avaliadas foram coloração da casca, sólidos totais, $\mathrm{pH}$, perda de massa fresca. Os dados foram submetidos a testes de normalidade e homogeneidade, atendidas as pressuposições, foram realizadas as análises de variâncias, com significância aferida através do teste $F(p<0,05)$. Por se tratar de fontes variação quantitativas (concentrações do óleo e épocas de avaliação), foram realizadas análises de regressão para todas as variáveis menos para o método por escala de notas. Em relação à coloração da casca dos frutos, o óleo do coco babaçu teve efeito relevante, sendo o tratamento com concentração de $5 \%$ de óleo de babaçu, o que manteve a coloração da casca verde por mais tempo que os outros tratamentos. De acordo com os resultados obtidos, o uso do óleo de coco babaçu na conservação pós-colheita de banana 'Pioneira' teve efeitos significativos, pois todos os tratamentos com concentrações de óleo de babaçu demonstram eficiência ao induzir o retardamento da maturação, sobretudo proporcionando o retardamento da elevação do teor de ${ }^{\circ}$ Brix nos frutos.

PALAVRAS CHAVE: acondicionamento, biofilmes, Musa AAAB.

\section{INTRODUCTION}

Banana is a climacteric fruit and among the most consumed in Brazil and in the world in its natural form, as it is source of carbohydrates, vitamins and minerals. Its production grows in Brazil, especially in family farming, highlighting the economic and social relevance of this culture. The fruit has high socioeconomic importance due to its good acceptance by Brazilian consumers (FAO, 2017).

Banana is a climacteric fruit and among the most consumed in Brazil and in the world in its natural form, as it is source of carbohydrates, vitamins and minerals. In addition to being a nutritious fruit, banana plays an important socioeconomic role in the communities of family farmers, as it guarantees the settlement of workers in the countryside and generates jobs in the field (Aquino et al., 2016).

Banana intended for marketing must have quality characteristics that are attractive to the consumer market, such as uniform colour, good physical quality, free from mechanical damage. However, due to its high perishability, large part of fruits produced reaches the market with the appearance indicating low quality, contributing to product depreciation and increased losses, mainly because most post-harvest technologies are not accessible to producers (Oliveira and Santos, 2015).

An alternative technique considered as viable to increase the post-harvest useful life of fruits and vegetables, processed or not, is the use of edible protective coatings. They are not intended to replace the use of conventional packaging materials or even definitively eliminate the use of cold, but rather to present a functional and supporting function, contributing to the preservation of texture and nutritional value, reducing surface gas exchange and excessive water loss or gain (Assis and Britto, 2014).

In this context, the aim of this work was to evaluate a practical and easily accessible alternative to banana producers that would contribute to reduce quantitative and qualitative post-harvest losses during storage, transportation and marketing of bananas, aiming to extend the post-harvest life of fruits and to analyze the effects of different babassu coconut oil concentrations as a coating on 'Pioneira' banana fruits (Musa AAAB).

\section{MATERIAL AND METHODS}

'Pioneira' banana variety (Musa AAAB), from the "Flor da Terra" farm in the district of Macaúba, municipality of Araguatins - TO, with geographic coordinates at $05^{\circ} 39^{\prime} 04^{\prime \prime S}$ and $48^{\circ} 07^{\prime} 28^{\prime}$ " W, altitude of $103 \mathrm{~m}$ a.s.l. was used. The region is characterized by hot weather, dry winter and rainy summer, and average annual rainfall of around $1500 \mathrm{~mm}$ and temperature of $28.5^{\circ} \mathrm{C}$ (INMET, 2017).

Fruit collection was carried out in the last hours of the day when temperature is lower. Four bunches at maturation stage 2 (green with yellow spots) were selected. Subsequently, fruits were immersed in container with water and neutral detergent to remove latex and dirt from the field. After washing with detergent, fruits were rinsed with $0.5 \%$ sodium hypochlorite solution in order to promote disinfection. Soon after this process, fruits were packed in plastic boxes with care to avoid any type of mechanical damage, and were later transported to room for the conduction of experiments, where fruits were homogeneously separated into bouquets containing three fruits. 
Then, fruits were packed in boxes and transported to the Laboratory of Soils of the Federal Institute of Education, Science and Technology of Tocantins, municipality of Araguatins - TO.

The experimental design adopted was completely randomized with four replicates, composing $6 \times 5$ factorial scheme (six babassu coconut purified oil concentrations as vegetable coating and five evaluation periods), totalling 120 experimental plots (each plot corresponded to a banana bouquet with 3 fruits), using 360 fruits in total.

Treatments consisted of different purified babassu coconut oil concentrations diluted in 1,000 mL of water at proportions of 1, 2, 3, 4 and 5\%, namely: control treatment without the use of coating (T1), coating treatments using babassu coconut oil diluted in water at 1\% (T2), 2.0\% (T3), 3.0\% (T4), 4.0\% (T5), $5.0 \%(T 6)$.

The coating solution with babassu coconut purified oil was prepared by diluting industrialized oil in one litter of distilled water at concentrations of 1: 100, 2: 100, 3: 100, 4: 100 and 5: 100; then, the solution was stirred in order to promote mixing. Evaluations were carried out on fruits in five times on the $1^{\text {st }}, 3^{\text {rd }}, 6^{\text {th }}$ and $9^{\text {th }}$ and $12^{\text {th }}$ days after coating application.

Fruits were immersed in solutions for one minute in order to cover their entire surface, being then placed in disposable dishes and stored at average temperature of $28.5^{\circ} \mathrm{C}$ and average relative humidity of $67 \%$. Temperature and humidity of the place where experiments were conducted were determined using hygrometer with direct reading (Figure 1).

Figure 1. Average temperature and air humidity during the experimental period

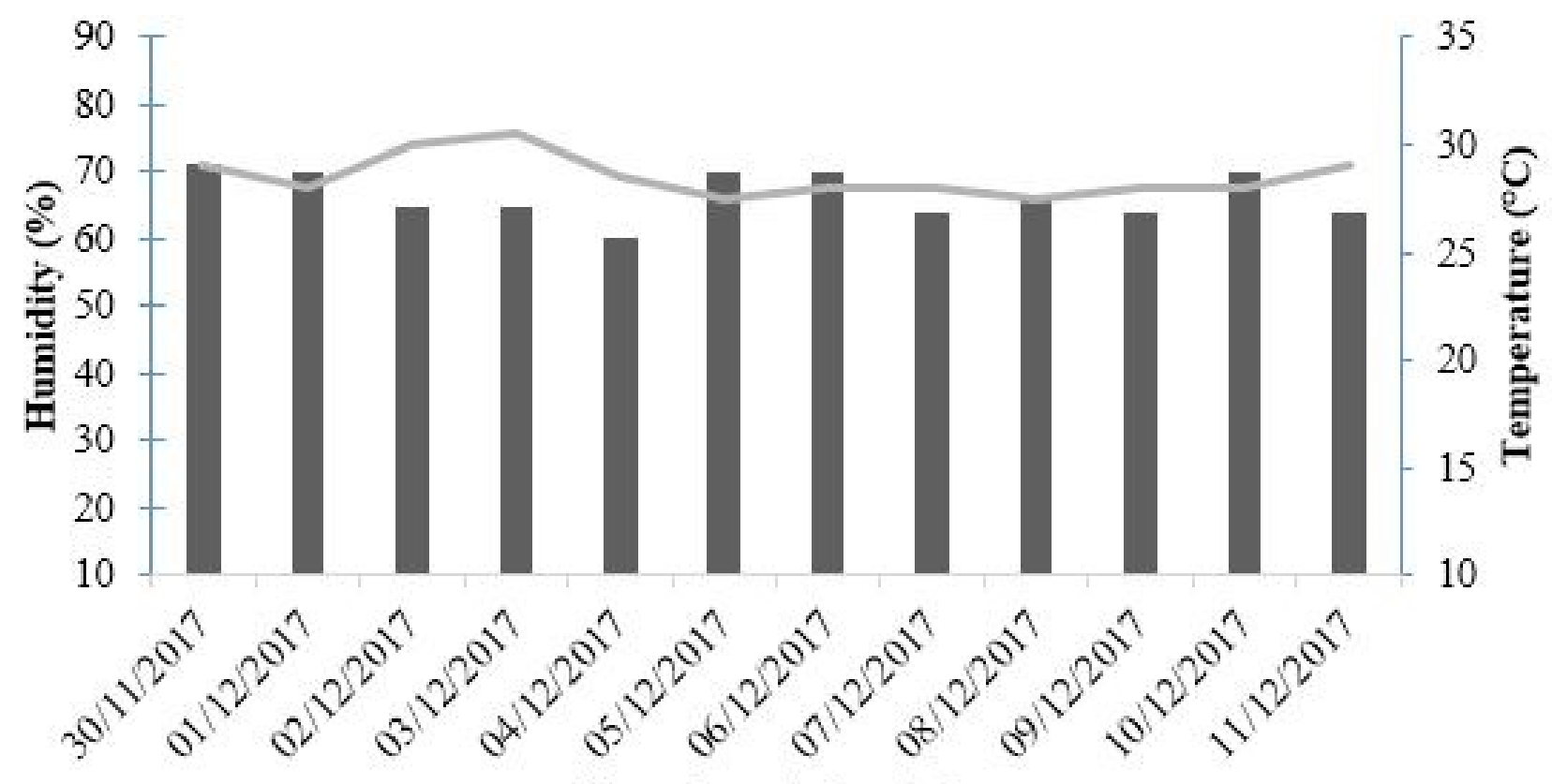

\section{Experimental period}

Humidity $(\%) \quad$ Temperature $\left({ }^{\circ} \mathrm{C}\right)$

In physical analyzes, peel colour and fresh mass loss were determined. In the chemical characterization, $\mathrm{pH}$ and total solids content ( $\left.{ }^{\circ} \mathrm{Brix}\right)$ were evaluated. Variables were analysed according to methodology described by Abreu (2017), detailed below:

Peel colour: determined according to visual assessment (score criterion) according to the Von Loesecke score scale (PBMH and PIF, 2006), as follows: 1 (totally green), 2 (green with yellow spots), 3 (more green than yellow), 4 (more yellow than green), 5 (yellow with green tips), 6 (completely yellow), 7 (yellow with brown spots).

Fresh mass Loss: determined from differences in the initial weight observed at the beginning of the experiment and the final weight of each storage period. Fresh mass was measured on a digital semi-analytical 
scale with precision of $0.1 \mathrm{~g}$, and results expressed as percentage $(\%)$.

$\mathrm{pH}$ : determined by means of digital potentiometer previously calibrated with standard solutions of $\mathrm{pH} 7.0$ and 4.0 by immersing the electrode in juice obtained by grinding 5 grams of pulp (extracted from a central portion of each of the 3 fruits) using blender and diluted in $50 \mathrm{ml}$ of distilled water.

Total Solids (ST): determined by obtaining a homogeneous paste from the median portion of each fruit using a small amount to determine the direct reading on digital refractometer, with range from 0 to 32 ${ }^{\circ}$ Brix and results expressed in ${ }^{\circ}$ Brix.

Data obtained were submitted to normality tests by Shapiro Wilk and homogeneity of error variances. Once assumptions were met, analyses of variances were performed, with significance measured through the $F$ test $(p<0.05)$. As these are sources of quantitative variation (oil concentrations and evaluation times), regression analyzes were performed for variables fresh mass loss, $\mathrm{pH}$ and total soluble solids, using the Sisvar statistical software, version 5.4.

\section{RESULTS AND DISCUSSION}

According to fruit colour (Figure 2), treatments T2 (babassu coconut oil at 1.0\% concentration), T3 (babassu coconut oil at 2.0\% concentration) and T4 (babassu coconut oil at $3.0 \%$ concentration) showed the same evolution of the maturation stage in all evaluations, presenting average score 2 (green with yellow spots) in the second assessment on the $3^{\text {rd }}$ day after treatment (DAT), score 4 (more yellow than green) on the $6^{\text {th }} \mathrm{DAT}$, score 6 (yellow) on the $9^{\text {th }}$ day after treatment and at the end of evaluations, it reached average score 7 (yellow with brown spots). For treatment T1 (Control), average score 3 (more green than yellow) was reached on the $3^{\text {rd }}$ DAT, evolving to score 7 (yellow with brown spots) on the $12^{\text {th }}$ DAT.

Figure 2. Scores for peel colour of "Pioneira" banana submitted to different babassu coconut oil concentrations as coatings, where: 1 (fully green), 2 (green with yellow spots), 3 (more green than yellow), 4 (more yellow than green), 5 (yellow with green tip), 6 (yellow) and 7 (yellow with brown spots).

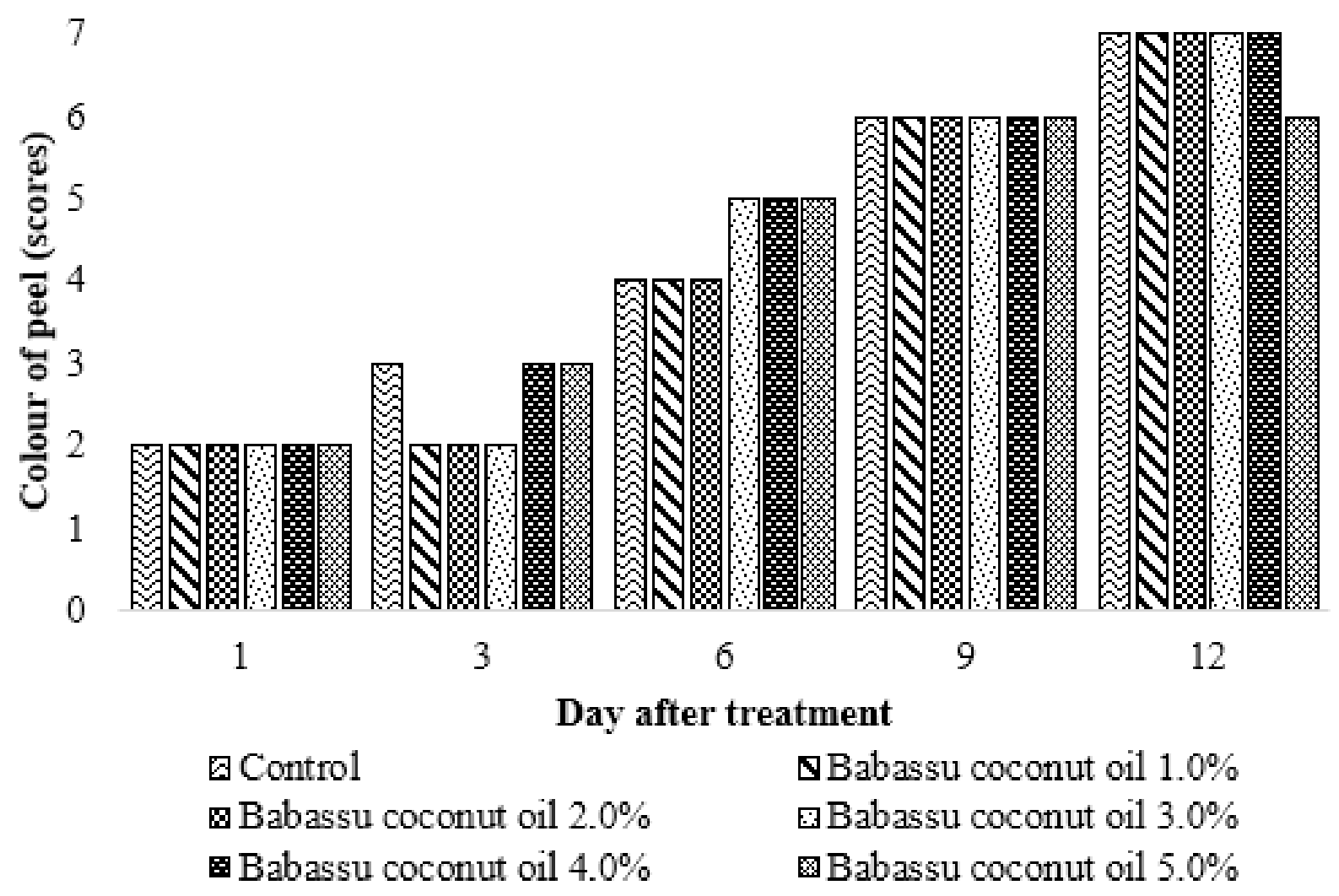

Treatment T5 (babassu oil at $4 \%$ concentration), evolves to score 4 (more yellow than green) on the $3^{\text {rd }}$ DAT and reaching score 7 (yellow with brown spots)

on the $12^{\text {th }}$ DAT. T6 (babassu oil at $5 \%$ concentration) obtained score 3 at the $3^{\text {rd }}$ DAT, evolving to average score 6 at $12^{\text {th }}$ DAT. According to Lucena et al. (2004), 
oil-based treatments proved to be efficient in delaying fruit ripening, probably because the oil formed a waterproofing layer, preventing the action of ripening inducer, acting as a type of modified atmosphere.

The colour degree of the banana peel is one of the important indicators of its shelf life, and is thus often used as guide for its retail distribution (Montibeller et al. 2016).

Lucena et al. (2004) evaluated the use of alternative treatments in "Nanicão" banana cultivar and found that soybean oil-based treatments at different concentrations induced delay in fruit ripening for up to 15 days at temperature around $25{ }^{\circ} \mathrm{C}$, with the exception of treatment at lower concentration (1.25\%), which at 15 days showed maturity degree and acceptable sugar content for consumption, which did not differ significantly from control.
Vieira et al. (2009) evaluated the use of edible coating with sunflower oil to maintain the quality of 'Tommy Atkins' mango in ambient conditions and observed that the addition of sunflower oil to the coating allowed fruits to acquire satisfactory colour for marketing, a slightly glossy appearance, which can influence the consumer's choice of fresh fruits.

Analysing the regression equation obtained for fresh mass loss of fruits (Figure 3), significant effects were observed only when analysing the evaluation times. It was then found that, over time, the process of fresh mass loss continued to progress for all treatments. This loss is related to water that is in greater proportions in fruits that are still green, but as they ripe, water levels tend to fall as transpiration increases (Lucena et al., 2004).

Figure 3. Fresh mass loss (\%) of 'Pioneira' banana fruits as a function of different storage times.

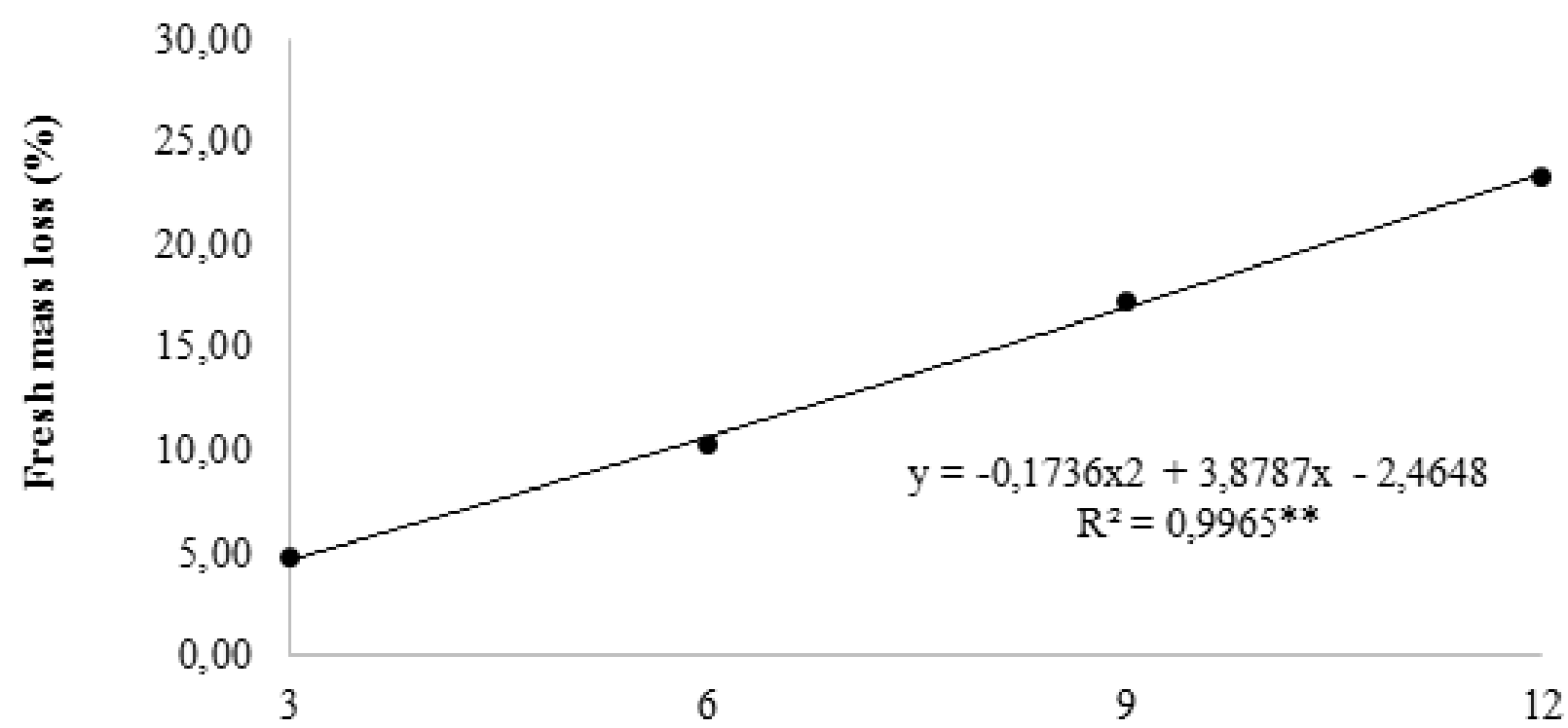

\section{Different storage times (days)}

Faster fresh mass loss of plant products can be explained by the difference in vapour pressure between product and environment, defined as vapour pressure deficit (Chitarra and Chitarra, 2005), being influenced by differences in relative air humidity of the product and the storage environment temperature (Chitarra and Chitarra, 1984; Luengo and Calbo, 2011). Thus, fresh mass losses obtained in evaluation times may have been due to the low relative air humidity $(67 \%)$ and high temperatures $\left(28.5^{\circ} \mathrm{C}\right)$ of the storage environment.

Silva et al. (2015) analysed the post-harvest conservation of 'Maçã' bananas with edible coating based on cassava starch and observed that fruit mass loss was not influenced by the application of biofilm, since both $0 \%$ and $8 \%$ fruits showed increase in fresh mass loss during storage.

In the regression analysis, the best adjustment in relation to evaluation times, regarding $\mathrm{pH}$ values of banana fruits was obtained by the quadratic polynomial equation in a highly significant way (Figure 4). It could be observed in the present study that the $\mathrm{pH}$ values had significant reduction at the 9th DAT, shortly after this period, increase was observed. 
Figure 4. pH values (hydrogen potential) in 'Pioneira' banana fruits as a function of different storage times.

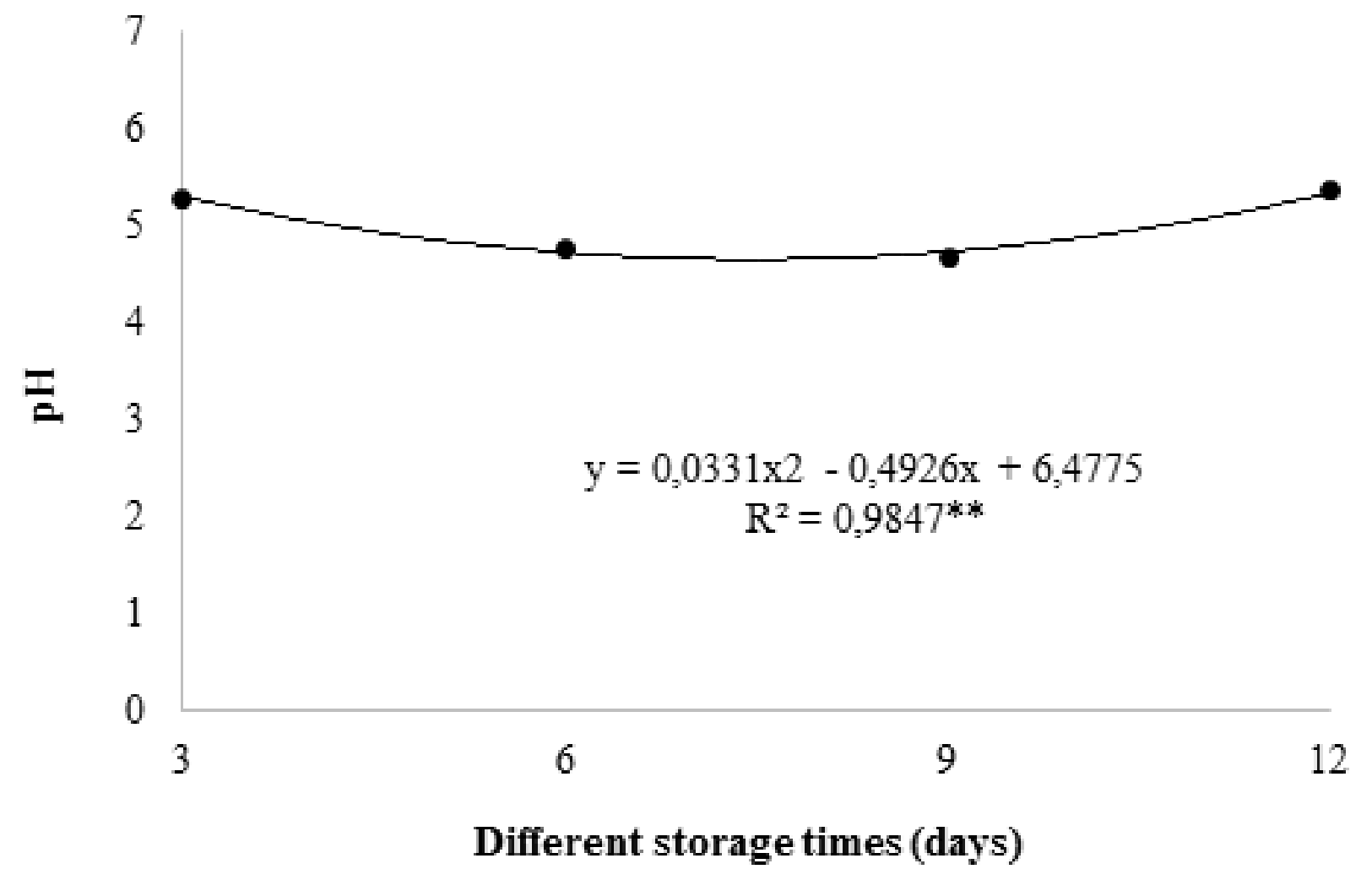

The result is similar to that found by Barbosa at al. (2019), in which the aim was to evaluate the effect of different temperature conditions on chemical and physical parameters of 'Pacovan' banana fruits stored for 12 days.

$\mathrm{pH}$ is associated with flavour, since acidity is able to reduce the perception of sugar and its decrease ends up by increasing sweetness, in many cases, even maintaining the amounts of sugar. $\mathrm{pH}$ is determined with the aid of $\mathrm{pH}$ meter, while acidity is calculated in percentage in relation to the predominant acid in the fruit, in the case of bananas, malic acid. Initially, there is increase in titratable acidity up to a maximum value, which coincides with the moment when the peel is fully yellow, followed by reduction in this value (SORADECH et al., 2017).

Silva et al. (2015) analyzed the post-harvest conservation of 'Maçã' bananas with edible coating based on cassava starch and found that $\mathrm{pH}$ values varied during the storage period, with gradual reduction, reaching minimum point at 9 and 11 days.
Lucena et al. (2004) observed significant $\mathrm{pH}$ reduction in 'Nanicão' bananas coated with cassava starch until the $6^{\text {th }}$ day of storage, and after this period, there was an increase in $\mathrm{pH}$. Treatment with $4 \%$ starch showed a drop and soon later an increase in $\mathrm{pH}$ at the end of the experiment, which can be justified by the consumption of acids at the respiratory peak referring to fruit senescence (Sarmento, 2012).

For variable total solids (TS), there was no significant interaction between babassu coconut oil concentrations and evaluation times; however, there was significant effect both for concentration and evaluation times separately. Thus, it was observed that babassu coconut oil concentrations promote a delay in the elevation of levels of total soluble solids ( ${ }^{\circ}$ Brix), and that control treatment (T1) obtained the highest levels of total solids, with average of 16.99 - Brix and treatment 2 with 1\% babassu coconut oil obtained the lowest value (TS), with average of 13.49 ${ }^{\circ}$ Brix (Figure 5). 
Figure 5. Total solid content (TS) of 'Pioneira' banana fruits as a function of different babassu coconut oil concentrations

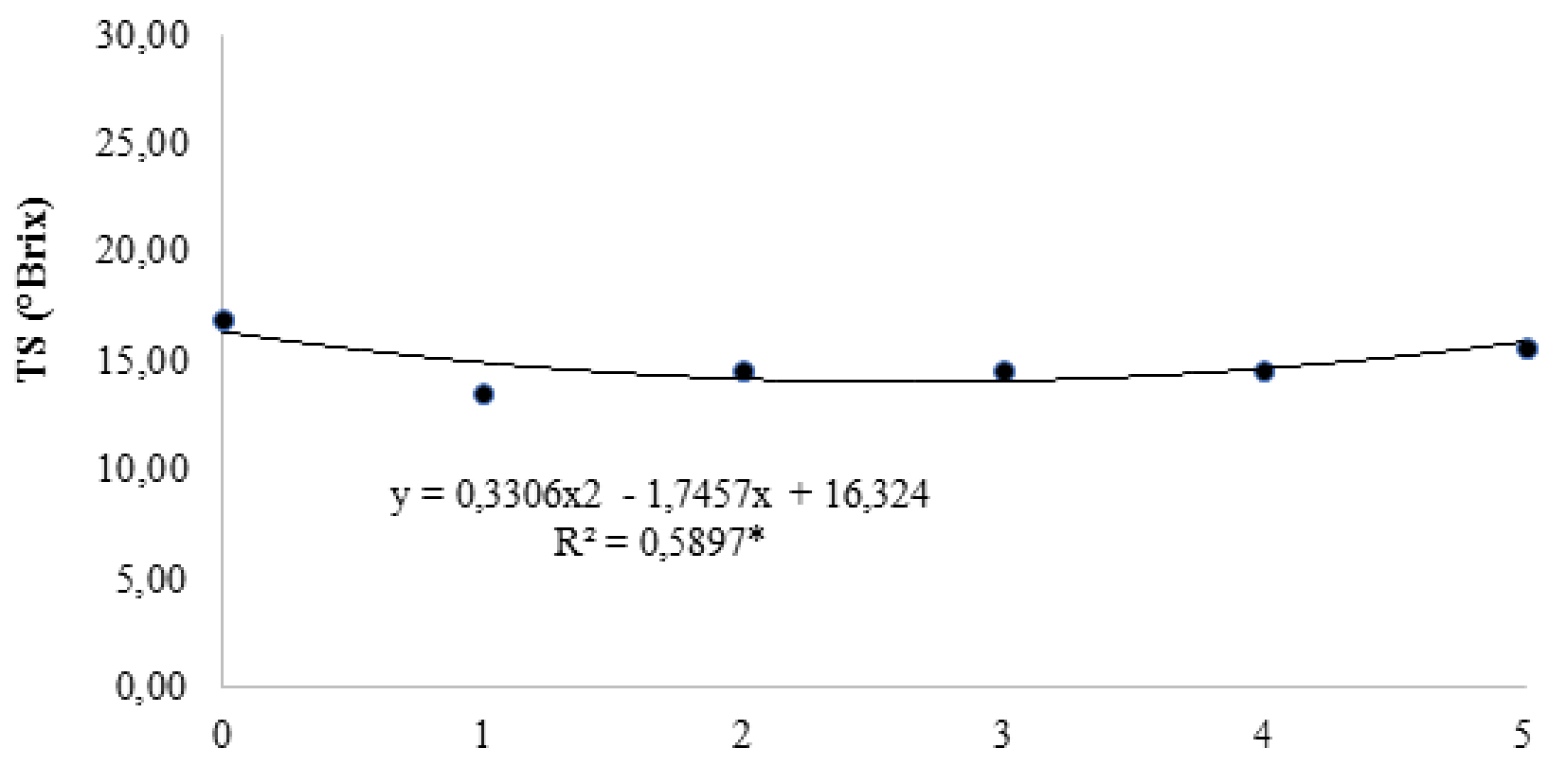

Babassu coconut oil concentrations (\%)

The increase in the levels of total soluble solids ( ${ }^{\circ}$ Brix) during the ripening period of fruits occurs mainly due to the conversion of starch into sugars; however, biofilms have the function of delaying fruit ripening (Silva et al., 2011).

Abreu (2017) evaluated alternative coatings for post-harvest conservation of 'Mysore' banana and observed that the results showed that treatment fruits (babassu coconut oil at $4 \%$ and $8 \%$ concentration) had lower levels when compared with fruits of the other treatments, presenting average values of 12.79 and $11.399^{\circ}$ Brix, respectively, showing the efficiency of oil in acting as a factor that contributes to the conservation of fruits in relation to TS maintenance.

Lucena et al (2004) verified alternative treatments in the post-harvest of "Nanicão" banana and observed that soybean oil-based treatments at different concentrations $(50 \mathrm{ml}, 25 \mathrm{ml}$ and $12.5 \mathrm{ml}$ ), presented the lowest levels of total solids at 12th DAT, and concentrations of $25 \mathrm{ml}$ and $12.5 \mathrm{ml}$ at 15th DAT had average levels of 8.0 to $18.0^{\circ}$ Brix.

Regarding storage times, it could be observed that over time, fruits tend to increase the ${ }^{\circ}$ Brix content, a phenomenon that occurs mainly due to the conversion of starch into sugars. There was an average of $7.73^{\circ} \mathrm{Brix}$ in the first assessment, which was observed on the 3rd DAT and on the last day of analysis, 12th DAT, the average was $18.96{ }^{\circ}$ Brix (Figure 6).

The increase in values of total solids occurs as a result of starch hydrolysis, causing the release of simple sugars. Using as indirect measure of sugar content, total solids are components with good representativeness, and their values increase according to the amount of sugars that accumulate in fruits, which occurs over time (Rocha and Uribe, 2018).

Babassu oil-based treatments demonstrate efficiency by inducing maturation delay for up to 12 days at temperature of $28.5^{\circ} \mathrm{C}$, extending the shelf life of fruits and maintaining the green peel colour for longer periods.

Babassu oil is an alternative product with low cost, easy access to local producers and satisfactory results for use as coating of banana fruits with a view of post-harvest conservation. Thus, further studies should be carried out using other oil concentrations, banana cultivars and fruit species at different maturation stages. 
Figure 6. Total solid content (TS) of 'Pioneira' banana fruits as a function of different storage times

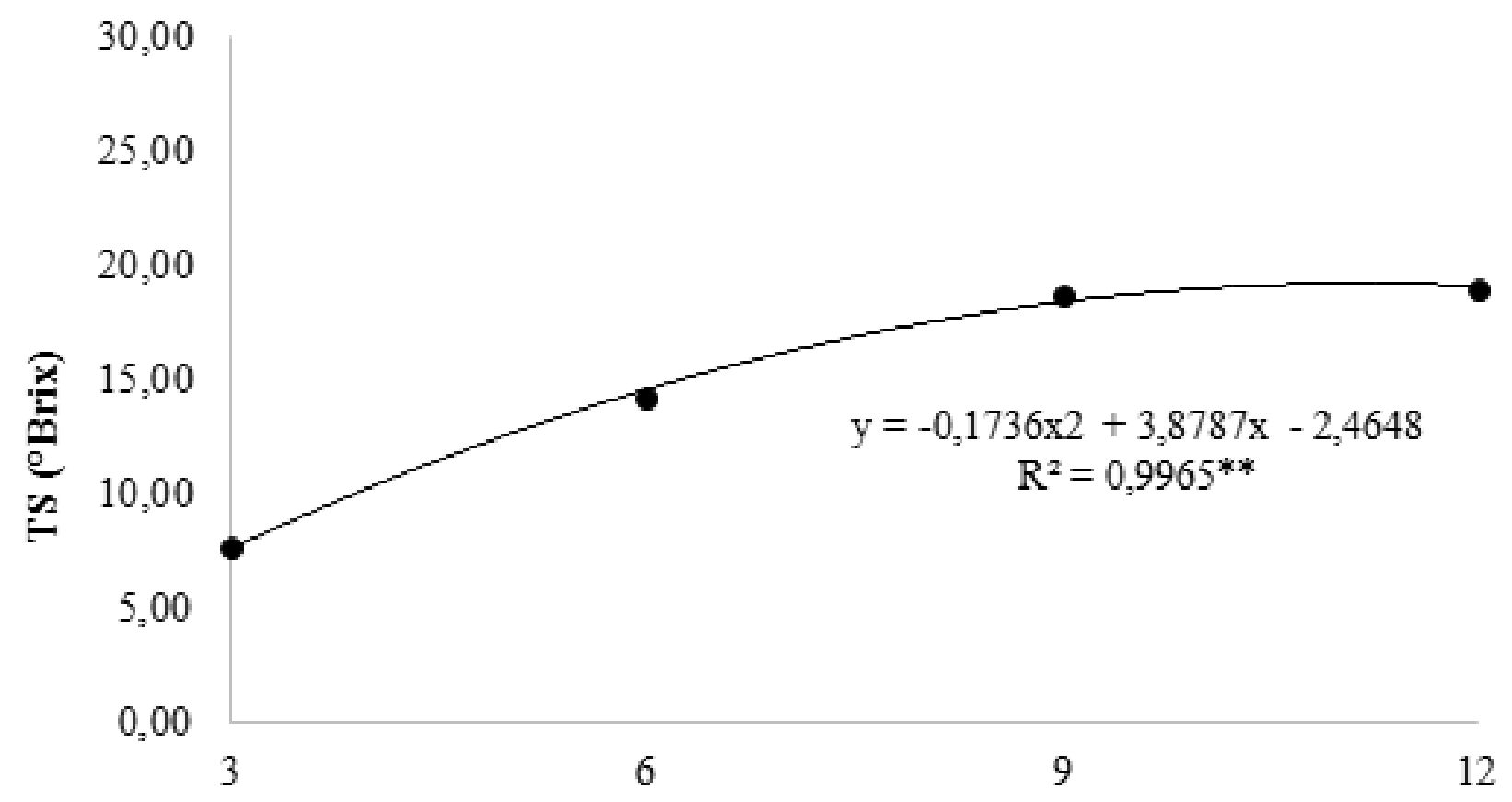

\section{Different storage times (days)}

\section{REFERÊNCIAS BIBLIOGRÁFICAS}

Abreu, P. C. Revestimento alternativos para conservação pós-colheita de banana 'Mysore'. 2017. 46 f. Trabalho de Conclusão de Curso (Bacharelado em Agronomia) - Instituto Federal de Educação do Tocantins, Campus Araguatins, 2017.

Assis, O. B. G.; Britto, D. Revisão: coberturas comestíveis protetoras em frutas: fundamentos e aplicações. Brazilian Journal of Food Technology, 2014, 17, 2, 87-97.

Aquino, C. F.; Salomão, L.C. C.; Azevedo, A. M. Qualidade pós-colheita de banana 'Maçã' tratada com ácido giberélico avaliada por redes neurais artificiais. Pesquisa Agropecuária Brasileira, 2016, 51, 7, 824-833.

Barbosa, L. F. S.;Alves,A. L.; Sousa, K. D. S. M.; Figueiredo Neto, A.; Cavalcante, Í. H. L.; Vieira, J. F. Qualidade póscolheita de banana 'Pacovan' sob diferentes condições de armazenamento. Magistra, 2019, 30, 28-36.

Chitarra, M. I. F.; Chitarra, A. B. Pós-colheita de frutas e hortaliças: fisiologia e manuseio. 2. ed. ver., amp. Lavras: UFLA, 2005. 785p.
Chitarra. A. B.; Chitarra, M. I. F. Manejo pós colheita e amadurecimento comercial de banana. Pesquisa Agropecuária Brasileira, 1984, 19, 6, 761-771.

FAO, 2017. Corporate Statistical Database. Disponível em: <http://faostat.fao.org/site/567/default.aspx>. Acesso em: 06 de nov. 2019

IBGE - Instituto Brasileiro de Geografia e Estatística, Levantamento Sistemático da Produção Agrícola LSPA. Pesquisa mensal de previsão e acompanhamento das safras agrícolas no ano civil, 2017, 30, 1, 1-81.

INMET - Instituto Nacional de Meteorologia. Monitoramento diário, 2017. Disponível em: <http://sisdagro.inmet.gov.br:8080/sisdagro/app/ monitoramento/bhc>. Acesso em: 11 de dezembro. 2017.

Lucena, C. C.; Feitosa, H. O.; Rosa, R. C.; Silva, A. C.; Silva, A. C.; Busquet, R. N. B.; Coneglian, R. C. C.; Vasconcellos, M. A. S. Avaliação de tratamentos alternativos na pós-colheita de banana cv. "nanicão". Revista Universidade Rural: Série Ciências da Vida, 2004, 24, 1, 93-98. 
Luengo, R. F. A.; Calbo, A. G. Pós-colheita de hortaliças: o produtor pergunta, a Embrapa responde. Embrapa Informação Tecnológica, Brasília, DF: 2011. 251p.

Montibeller, M. J.; Zaparolli, F. B.; Oliveira, B. G.; Pietrowski, G. D. A. M.; Almeida, D. M. Efeito de filmes de polímeros naturais na conservação de banana cv. caturra (Musa paradisiaca L.). Revista Brasileira de Produtos Agroindustriais, 2016, 18, 1, 11-19.

Neris, T. S.; Sousa, S.; Loss, R. A.; Carvalho, J. W. P.; Guedes, S. F. Avaliação físico-química da casca da banana (Musa spp.) in natura e desidratada em diferentes estádios de maturação. Ciência e Sustentabilidade, 2018, 4, 1, 5-21.

Oliveira, E. N. A. D.; Santos, D. D. C. (Org.). Tecnologia e processamento de frutos e hortaliças. Natal: IFRN, 2015. $234 p$.

PBMH \& PIF. Programa Brasileiro para a Modernização da Horticultura \& Produção Integrada de Frutas. Normas de classificação de banana. São Paulo: CEAGESP, 2006.

Rocha, K. R.; Uribe, S. J. Relação amido e açúcares solúveis durante o processo de maturação da banana 'prata'. Revista Tecnologia \& Ciência Agropecuária, 2018, 12, 2, 51-56.
Sarmento, C. A. R.; Oliveira, L. F. M.; Souza, J. P. S.; Santos, M. C.; Santos, J. R.; Carvalho, C. R. D.; Leite, G. V.; Oliveira Junior, L. F. G. Desenvolvimento de Protocolo para Determinação do Ponto de Colheita de Bananas Variedade Princesa. In: XIII Congresso Brasileiro de Fisiologia vegetal e XIV Reunião LatinoAmericana de Fisiologia Vegetal, 2011, Buzios. Brazilian Journal of Plant Physiology, 2011, 23.

Silva, A. M.; Ambrósio, M.; Nascimento, D. S.; Albuquerque, A. N.; Krause, W. Conservação póscolheita de banana 'Maçã' com revestimento comestível a base de fécula de mandioca. Centro Científico Conhecer, 2015, 2, 3, 23-34.

Silva, D. F. P.; Siqueira, D. L.; Santos, D.; Machado, D. L. M.; Salomão, L. C. C. Recobrimentos comestíveis na conservação pós-"colheita de 'Mexerica-do-Rio'. Revista Brasileira de Fruticultura, 2011, 33, 1, 357-362.

Soradech, S.; Nunthanid, J.; Limmatvapirat, S.; Luangtana-Anan, M. Utilization of shellac and gelatin composite film for coating to extend the shelf life of banana. Food Control, 2017, 73, 1310-1317.

Vilas Boas, E. V. B.; Alves, R. E.; Filgueiras, H. A. C.; Menezes, J. B. Características da fruta. In: Matsuura, F. C. A.; Folegatti, M. I. S. Banana: Pós-colheita. 1. ed. Brasília, DF: Embrapa Informações Tecnológica, 2001. 